This item was submitted to Loughborough's Research Repository by the author.

Items in Figshare are protected by copyright, with all rights reserved, unless otherwise indicated.

\title{
Nationalism, the nation and migration: searching for purity and diversity
}

PLEASE CITE THE PUBLISHED VERSION

http://www.ingentaconnect.com/content/routledg/cspp/2010/00000014/00000003/art00002

PUBLISHER

(c) Taylor and Francis

VERSION

AM (Accepted Manuscript)

LICENCE

CC BY-NC-ND 4.0

REPOSITORY RECORD

Mavroudi, Elizabeth. 2019. "Nationalism, the Nation and Migration: Searching for Purity and Diversity". figshare. https://hdl.handle.net/2134/8835. 
This item was submitted to Loughborough's Institutional Repository (https://dspace.lboro.ac.uk/) by the author and is made available under the following Creative Commons Licence conditions.

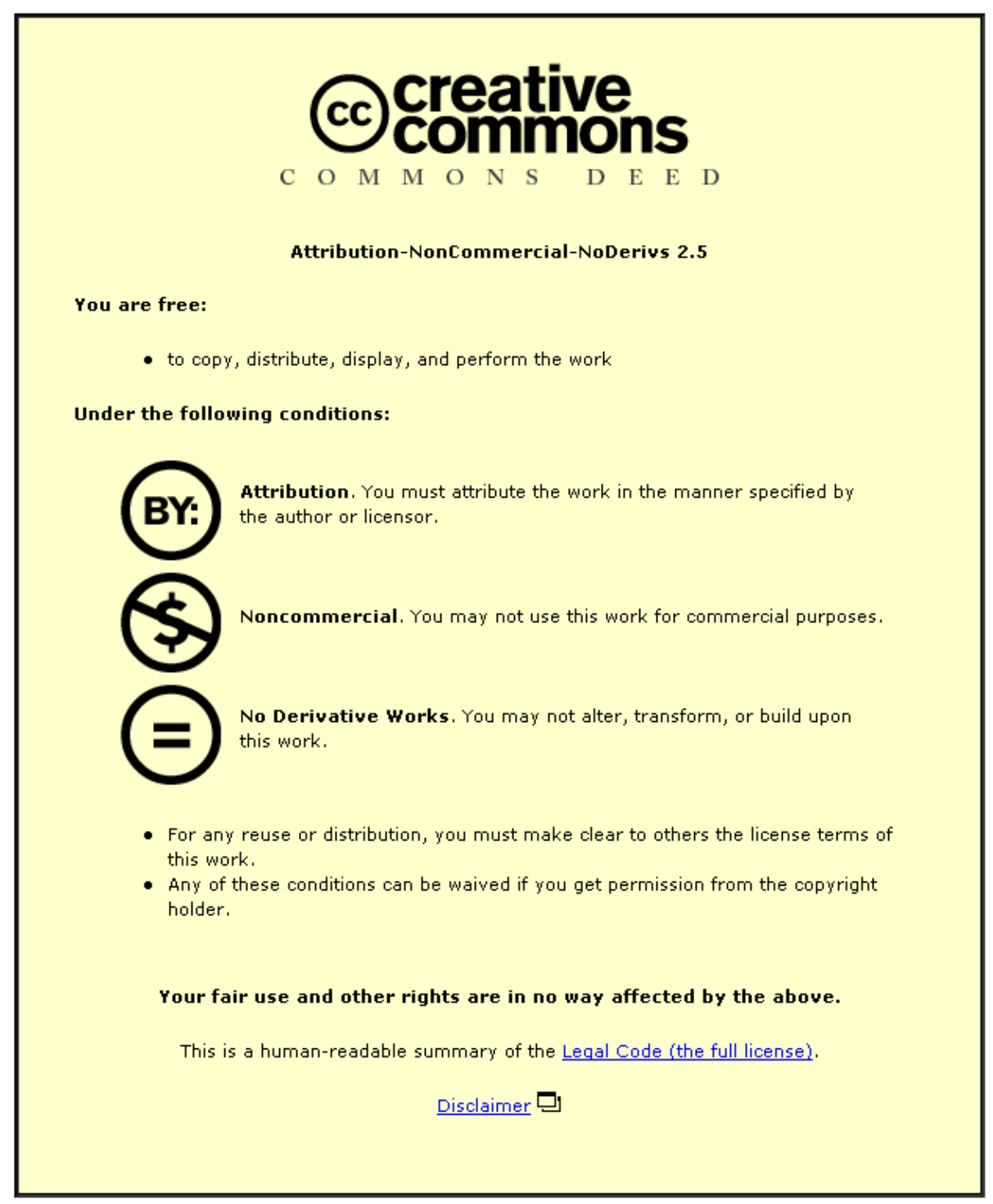

For the full text of this licence, please go to: http://creativecommons.org/licenses/by-nc-nd/2.5/ 


\title{
Nationalism, the nation and migration: searching for purity and diversity
}

\begin{abstract}
This paper adds to debates on the double-edged and contested nature of nationalism and its relationships with migration and diaspora. It does this by focusing on the notion of purity and highlights the ways in which national identities can be based on homogenising constructions of the nation. In an age where the nation-state system and migration are both important and in which there are recurring politicised uses of nationalism in potentially extreme ways, the paper discusses how nationalism can be problematic. It calls for contextualised and grounded research on the everyday meanings of nationalism in order to emphasise the messy and often ambivalent nature of national identities. In this way, it argues that there is potential for 'rescuing nationalism' as a more inclusive, diverse notion.
\end{abstract}

Keywords: nationalism, national identity, migration, diaspora, purity, diversity

\section{Introduction}

National identity is a much debated and contested notion and one that is being re-thought and deconstructed to make it relevant to contemporary societies. Despite disagreements on how nationalism initially materialised, scholars generally agree that the nation-state system, and the national identity that accompanies it, is still relatively strong (see, for example, Marden 1997; Triandafyllidou 1998; Ong 1999). Nationalism and national identity have become regarded as ways in which states are able to control and manipulate belonging within defined boundaries, which are located within and across territorial state borders. Nationstates are still assumed to form part of the nation-state system which migrants and those in diaspora may be seen as challenging or transgressing. However, they still inhabit a world of states into which nations are messily and often arbitrarily placed. States, therefore, remain 
important as repositories of governance and legality. States place ideological and hegemonic demands on their citizens in terms of attachment and belonging in the form of national identity as they attempt to mould and unite the 'nation' (Kong and Yeoh 1997). Therefore, although one could argue that nationalism may be changing, it is not necessarily becoming more inclusive or open-ended; there are still numerous more closed, exclusive and narrowly defined nationalisms. Nationalism, despite its potential for unity, liberation and collectivity, has a tendency towards purity and homogeneity, even in the $21^{\text {st }}$ Century.

Although there is often an assumption that migration and globalisation are creating more hybrid, creolised and in-between identities, nationalism continues to be an important aspect of people's lives and the state. On the one hand, within host societies, factors such as marginalisation and perceptions of Others as threatening can create inward-looking tendencies and a need to regain or hold onto cultural, national, regional and other forms of place-based purity and attachment. On the other hand, those 'on the move' themselves may seek to deal with potential xenophobia, dislocation and vulnerability by relying on more homogenous and purist notions of ethnic, religious, cultural or national identity that are often linked to the homeland.

The main aim of this paper is to illustrate that purity continues to be an underlying feature of many constructions of national identity and nationalism, despite the rhetoric of multiculturalism, diversity and heterogeneity and that as a result, nationalism needs to be radically rethought in more inclusive, plural ways. The paper argues for more 
grounded examples into the complex ways in which nationalism is constructed, experienced and perceived on an everyday basis, over time and at a variety of interacting scales and spaces. It is important to explore how notions of purity, diversity, inclusion and exclusion as well as diversity and inclusion underpin belonging and constructions of the 'nation'. In particular, there is a need to examine the ways in which nationalism can be 'rescued', made more meaningful to people and include rather than exclude those potentially deemed as Other, such as migrants and those in diaspora.

\section{Problematizing nationalism}

The paper is based on understandings of nation and nationalism as socially constructed; however, this is at odds with understandings of nationalism as primordial or ethno-nationalism (A.D Smith 1999; Cohen 1999). Yet such theories of ethno-nationalism remain popular, particularly amongst those involved in long-distance nationalism and selfdetermination. At the same time, one could argue that all conceptions of nationalism have, as their basis, a fundamental desire for purity, despite the diversity that exists within nations and societies. Migrants and those in diaspora are often seen to contribute to such diversity; yet they are sometimes seen as problematic for nation-states trying to create and maintain often quite singular notions of national identity as part of the national and cultural unification project.

Nationalism can be more homogenising, purist and potentially exclusionary. For example, Gilroy (1999), Anderson (1999) and Carter 
(2003) have all warned of the dangers of extreme nationalism and absolutism. Violence and oppression associated with more extreme forms of nationalism can clearly not simply be relegated to non-Western 'others' (Wimmer and Glick-Schiller 2002, p.307). The tendency for nationalism to be both positive and potentially problematic has also been highlighted by Said (1990, p.359) whilst referring to the case of Palestinians in exile:

Nationalism is an assertion of belonging in and to a place, a people, a heritage. It affirms the home created by a community of language, culture and customs and by doing so, it fends off exile, fights to prevent its ravages...all nationalisms in their early stages develop from a condition of estrangement.

Here, Said appears to accept that constructions of nationalism need a defined territorial homeland, common culture, language and identity and that as a result can become:

'defensive, xenophobic, politically amenable to the kind of manipulation that has produced ethnic and religious conflict as well as partitions of multicultural societies into their separate little entities who can snarl at eachother across their barbed-wire borders forms of nationalism (Said 2001, p. 141). 
Yet, elsewhere Said has stressed the importance of recognizing the hybrid and diverse nature of what it means to be Palestinian (Said 1986). Said recognizes how nationalism can be exclusive and create us/them relationships that can be very difficult to dissipate after the "early stages". This highlights the exclusionary potential of nationalism, but also its ability to unite dispersed and fragmented groups, as in the case of Palestinians. It also raises the issue of how difficult it can be for some theorists to reconcile national, collective identities with more plural, fluid cultural identities. However, other theorists such as Papastergiadis (2004, p. 82, 85) are unequivocal in their distaste for nationalism:

The singular and uniform construction of identity within the boundaries of the nation now seems to be untenable. All cultures are plural and identity is never fixed.... The history of nation-state has always been a constant struggle to attain a sense of unity and coherence. The C19th dream that nation-state should compromise single culture with all people cohabiting that space sharing common identity has proved to be a (quite literally) bloody nightmare.

Although nationalism has been associated with many positive liberation, unification and independence movements, it clearly can also be exclusive, insular and dangerous, or as Fine (1999, p.154) calls it: "a fickle beast". It is this desire to create states that are somehow ethnically 'pure' that is problematic. Therefore, for all its positive aspects, 
nationalism is a potentially dangerous phenomenon, one that has is used as a tool for ideological control and surveillance, is often viewed in negative ways (Chatterjee 2005, p. 238) but is also undergoing challenges and changes that need to be explored.

The nation-state system is one that has been regarded as a positive way to control, govern and manage the world order, where 'nations are the natural units of society' (Taylor 1997, p. 197). So, if we take a classic definition on nationalism, by Smith (1999, p. 37), we can see that autonomy and commonality are important elements:

[nationalism is] an ideological movement for the attainment and maintenance of autonomy, unity and identity of a human population, some of whose members conceive it to constitute an actual or potential 'nation'. By a 'nation', I mean a named human population sharing a historical territory, common myths and memories, a mass public culture, a single economy and common rights and duties for all members.

This commonly used definition of nationalism has public and political appeal because of its insistence on homogeneity, stability and history. It is becoming increasingly invoked in politicised debates, even in supposedly tolerant and multicultural Western states. Such notions of nationalism go against ideas that all cultures are mixed in the first place; however, conceptions of nationalism that stress ethnic homogeneity continue to be privileged to a greater or lesser extent. Nationalism can 
create negative Us/Them distinctions and Othering discourses, whereby those deemed as different such as migrants and those in diaspora are perceived to be in need of incorporation into an imagined homogenised nation. As such, the nation is constructed as unified under certain norms such as societal behaviour, culture, religion, ethnicity, history and so forth (Shapiro 2000).

To imagine a state as a united whole requires discourses that hold together the nation within imagined communities (Anderson 1983), through collective memories (Said 2000), 'invented traditions' (Hobsbawm and Ranger 1983) and banal nationalism (Billig 1995). A 'shared consciousness' and shared history is perceived as being needed in order to unite people and often become remembered as the linear and irrefutable truth and disguise the fact that history is relative, subjective and open to different interpretations. As a result, certain historical events and representations are favoured over others, which may be ignored (see, for example, Allan and Thompson 1999, on the time-space of national memory and Nuttall and Coetzee 1998).

However, it is simplistic to assume that people are passive recipients of state-imposed and/or elite nationalism; there is agency in the process of belonging and feelings of nationalism are dynamic, active and may vary depending on factors such as age, gender and class. For example, Kong and Yeoh (1997) highlighted that not all Singaporeans wholeheartedly accepted the nationalistic rhetoric of the state during national day parades and Fenton (2007) has found that young people in Britain, whilst still feeling British are often indifferent about their national 
identity. Therefore, people can and do problematize nationalism within their everyday lives even as they operate within its realms. Certainly, there are people (who are not migrants or in diaspora) who find the homogenizing principles behind some forms of nationalism difficult to deal with, especially if it is presented in more extreme, patriotic ways (Abell et al 2007).

Nationalism may sit uneasily in the current talk of globalization, migration and cross-border connections as the world is imagined as infinitely and intricately intertwined. For example, Papastergiadis (2004) feels that globalization has created large strains on the ideal of the nation-state. Yet globalization is uneven and identities remain rooted at the local, regional and national level for many, despite the power relations and complex processes of place-making and cross-border connections that exist (Massey 2007).

\section{Migrants, diasporas, national identity and purity}

Migrants and those in diaspora and their cross-border connections have been seen as unsettling the perceived homogeneity of the 'nation', creating identities and cultures that are more 'in-between' and complex and that are seen as 'beyond' the nation. As a result, they are sometimes seen as problematic. There are countless historical examples of migration being ignored within the nation-building projects of states (see, for example, Castles and Miller 2003). Western states are seen as accommodating diversity and giving non-citizen migrants increasing rights (Varsanyi 2005) but at the same time, have increasingly restrictive 
immigration policies and border control (Meyers 2003; Cornelius 2005; Marfleet 2006; Van Houtum and Pijpers 2007; Winders 2007) and are retreating from multiculturalism (Mitchell 2004; Joppke 2004; Vasta 2007). Although immigration policies are often seen to be created for economic reasons, xenophobia by the public and a perceived need to control migration flows also have a strong influence on such policies (Schuster 2003). There are numerous examples where policies were created in order to promote purity and exclude those deemed to be too 'different' - a classic example is Australia's 'White Australia' policy which was terminated as recently as 1974 (Hage 2000). In the same way, other countries and areas are struggling to create inclusive spaces for immigrants because of homogenous constructions of national identity which have resulted in xenophobia and racism (Triandafyllidou 1998, 2000; Calavita 2005; Nyamnjoh 2006; Delanty 2008; Noble and Poynting 2008).

The ideal of the nation also has a close relationship with prejudice, racism and xenophobia (Balibar 2005). Historically, the building up of the nation-state has often coincided with reactionary and xenophobic constructions of the Other as for example, barbaric, uncivilized, and so forth. Therefore, those who are perceived as not belonging often become labeled as 'too' different and become seen as a threat to an imagined and racialized status quo. At the same time, there is the recurring issue of treatment of unskilled and low skilled migrants who are often needed for economic purposes but who are not necessarily welcomed as part of the nation. There is a similar situation 
occurring with asylum seekers and those who enter countries as undocumented migrants (and often do so because legal channels to migrate to the West are becoming increasingly difficult). They are often subject to prejudice and stereotyped in negative ways as criminals, for example (Hubbard 2005, Grillo 2005; Marfleet 2006). The 'liberal paradox' (Hollifield (2004) has meant that despite borders becoming more open for economic reasons and for highly skilled professionals, they are closing for low, unskilled migrants and asylum seekers.

Migration, therefore can promote patriotic and ultra nationalist tendencies in the host country. The fact that everyone (including migrants and those in diaspora) has the potential to construct more extreme nationalisms and be prejudiced towards others reminds us that despite the progress that some countries in the contemporary world have made in terms of tackling exclusion, racism and xenophobia, these issues continue to exist (see, for example, Poynting and Mason 2007 on Islamophobia). As Grillo (2003, p. 164) stresses "The problem... is not difference, but elevating it into an absolute, fundamental, humanitydefining trait, and using it as justification for the refusal of mixing". Grillo (1998, p. 134, cited in Grillo 2003, p. 167) highlights the continued attraction of cultural essentialism and the fact that "in contemporary Europe... nationalist, and, yes, racist, versions of a culture continue to dominate the popular imaginary". Such fear of difference and the ability to construct identities in very simplistic, purist ways may be at odds with the more fluid, malleable notions of identity-in-the-making that many cultural theorists such as Hall (1999), Clifford (1997) Gilroy (1999) and 
Bhabha (1994) have discussed. In the same way, those theorizing diasporic and migrant identities often do so in ways that highlight the hybridity and transgressive aspects of these identities (see, for example, Rapport and Dawson 1998; Yeoh and Huang 2000, p. 415).

Although important and relevant, such theories may not be able to adequately deal with and account for more extreme and purist notions of identity even as they may acknowledge that such notions of identity may occur. Also, although such work on hybridity and 'in-between' identities is often inspiring and powerful, life 'in the margins' is not necessarily easy and must not be romanticized. At the same time, hybridity itself is a contested notion, which has been criticized for being theoretical and literary rather than realistic and applicable to real people's lives (Rose 1995; Mitchell 1997). It has also been critiqued for presupposing purist elements that can then be mixed to become hybrid (Hutnyk 2005). Levy (2000, p. 7) also stresses that hybrid cultures can themselves lead to 'bounded communities' and exclusion. However, despite this, hybridity does offer a way to transgress more purist, essentialist constructions of identity.

Immigration and integration policies that are meant to encourage diversity, tolerance and social cohesion are often thinly disguised attempts to classify and categorize groups for easy recognition, 'tickboxing' bureaucracy, and are often contradictory (see, for example, Castles 2004; Schuster and Solomos 2004; Flynn 2005; Sales 2005). Despite its recognizing and respecting of cultural and religious difference (Parekh 2000), multiculturalism as a policy of migrant integration has 
been seen as problematic for creating group-based rights based on narrow definitions of culture potentially creating exclusion rather than inclusion and the illusion of equality (see Joppke 2004). Although the repercussions of multicultural policies in the UK remain contested, social cohesion, immigration and cross-cultural relations are seen as problematic and politicized issues for Western governments; in short, the increasing difference, pluralism and diversity that inevitably exists is often imagined as something to be feared and constrained and is seen to be in need of management to ensure effective governance and integration of minorities. At the same time, however, integration strategies may rest upon constructions of national and ethnic purity. Condor (2006), for example, highlights how the UK Labour party has had contradictory constructions of ethnic nationalism and she points out that they are more Anglocentric in their conceptions of British identity than they might realize. For her, their multicultural rhetoric, far from moving them away from this centrism, has increased their tendency to create ethno-nationalism based on narrow perceptions of what it means to be British despite espousing the rhetoric of pluralism.

To use another example, the US government has had an important role in 'designing' the 'melting pot' and has repeatedly illustrated its desire for immigrant exclusion as well as assimilation, highlighting the continued role that the state plays in controlling immigration (Zohlberg 2006). The Western state's need to control and classify such difference has led it to accept difference insofar as it does not interfere with the goals of the state. Although one might argue that a 
focus on the ideals of national community and identity is necessary for stable governance, Levy (2000) argues that diversity needs to be accepted as a reality of life rather than a goal to be implemented by state policy.

Despite the fact that Western democracies need to be seen to be inclusive, open-minded, and tolerant of their diverse populations, history continuously illustrates that this is easier said than done. Academics such as Parekh (2000), Amin (2002), Massey (2007), Grillo (2007), Vertovec (2007a), Fortier (2007) and Wise (2010) have all discussed the realities of dealing with diversity in a tolerant society in which difference is not just a euphemism for political correctness and in which there is no ideal solution to living with diversity. Amin (2002), for example, has argued that ethnicity is a mobile and incomplete process, and so he stresses the importance of going against current ethnic stereotypes. He emphasizes the very real cultural dynamism of minority ethnic (and white) communities as well as the micropolitics of everyday contact between people and the importance of placing people from different backgrounds in new settings where engagement with strangers in a common activity disrupts easy labelling of the stranger as enemy and initiates new attachments. He calls these moments of cultural destabilisation, which he believes offer individuals the chance to break out of fixed relations and fixed notions, and through this, to learn to become different through new patterns of social interaction, which may upset old hierarchies and preconceptions. 
Theories of migrant integration, particularly in the US, have stressed the importance of assimilation whereby migrants would somehow shed homeland identities and loyalties and become part of their new host society in an all encompassing sense; however, these have been critiqued in a variety of contexts (see, for example, Silberman et al 2007; Haddad and Balz 2006; Portes et al 2005; Ellis and Almgren 2009; Duprez 2009). At the same time, it is worth pointing out that most government policies on immigrant settlement and incorporation stress integration or assimilation as an endpoint and certainly for many Western governments, management of migration is seen as important (Spencer 2005).

The UK government has been keen to make migrants integrate by, for example, bringing in the citizenship test and by stressing the discourses of social cohesion and community (see Cantle 2001; Delanty 2003; Hudson et al 2007; Cheong et al 2007; Crowley and Hickman 2008). Social cohesion and community are contested notions, and are ones that are vague as well as sometimes ineffective. They imagine homogenous communities in which differences are subsumed into stereotypes of Us and Them; for cohesion to work, it is assumed that there must be integration of those who are visibly different but some have seen this as a difficult and contested matter. Although Britain is not seen as having 'ghettoes' or segregation (Phillips 2006; Peach 2009), there are continuing debates on the realities of integration and the settlement of migrants. For example, Abbas (2007), Valins (2000) and Phillips (2006) have commented on the realities of integration and so 
called 'self-segregation' in the UK whereby members of minority groups can 'retreat to their communities' in order to deal with hostility and to rely upon 'class and ethnic community resources' (Abbas 2007 p 290).

Integration of migrants is therefore a contested notion which stresses the need for migrants and those in diaspora to adapt to the host society and while it is not as extreme as the notion of assimilation, it assumes that we can define what migrants are integrating into, which raises questions about the definitions of national identity and culture. National identity, as a supposedly unifying force, can often be problematic for those who may have complex feelings of belonging. Yet, it can become something that immigrants can relate to and negotiate as part of multiple, fluid identities although this can be a difficult process, especially as transnational connections increase (see, for example, Dwyer 1999; Hussein and Bagguley 2005). In the same way, the host population can construct national identities and nationalism in inclusive, rather than exclusive ways.

Therefore, it is important to analyse what nationalism constitutes for those in diaspora on an everyday basis and how it may be perceived in positive, negative and problematic ways. National identity is clearly of interest to migrant and diasporic groups for different reasons across a variety of contexts and scales. For example, Waldinger (2007) has explored how migrants in Los Angeles 'naturalise' and become nationals. In the US, the edited collection by Massey (2008) highlights the different ways in which immigrants are shaping the geographies of America and the continuing ambivalence with which immigrants are treated. There are 
examples of inclusion, exclusion, marginalization, antipathy and adaption but the editors feel that on the whole, there is a broad acceptance of immigrants. Likewise, Citrin et al (2007) in their study on Mexican Americanization, found that Mexicans have come to feel more American through the generations. Nagel and Staeheli (2005) have also discussed how Arabs in the US and the UK have tried negotiated belonging and integration and as a result, their efforts are directed at the local and national scales as well as the transnational scales (see also Nagel 2002).

More recent notions of migration have focused on transnationalism and the increasing tendency for migrants to have transnational economic, social, cultural and political connections with their country of origin (Guarnizo and Smith 1998; Glick-Schiller et al 1999; Kivisto 2001; Vertovec 2004). Such transnational connections have raised governmental concerns about competing political loyalties and the ability of such migrants to integrate; however, research suggests that transnational migrants can and do negotiate complex, boundary crossing cultural and political identities and practices, which do not necessarily make national belonging problematic (see, for example, Portes et al 2008 and Pantoja 2005 on political participation of immigrants in the US).

If the notion of transnationalism is deconstructed, we come to realise that is based firmly within the realm of nation-states, hence, the idea of crossing or transgressing state boundaries or borders. It still very much sees the world as divided up into nation-states with their 
associated cultural and national identities, or as Wimmer and Glick Schiller (2002, p. 324) put it: 'transnationalism studies... reproduces the standard image of a world divided into nations and thus naturalizes this vision of the world in new forms'. The problem with transnational approaches and their bias towards the nation-state is perhaps their inability to examine how contemporary movements (metaphorically and physically) may be changing the nature of the state and of nationalism.

Diaspora is seen differently by scholars, some of whom do not see it as synonymous with transnationalism and some who do (Tölölyan 1991). Kastoryano (2007), for example, feels that transnational nationalism and diaspora nationalism are different in that diasporas unite around myths of nation and homeland whereas transnational migrants negotiate nationalism in more diverse and dynamic ways. However, others have argued that diasporic identities negotiated as in-between pose a challenge to the nation-state. Nationalism is conceived and practiced in different ways and although diasporas are traditionally seen as creating myths of a national homeland which unite them in exile, the reality is that there are many different definitions and uses of the notion of diaspora (Brubaker 2005). However, it is useful to highlight two distinct ways that diaspora has been theorized by scholars. On the one hand, diasporas are seen as distinct ethnic/religious/cultural groups and are traced from their original homeland to locations around the world (Sheffer 1999). They are perceived to be a united group, connected on the basis of identity and links to the homeland. On the other hand, the notion of 
diaspora has also become synonymous with syncretism, in-betweenness and an antidote to the homogenization of nationalism.

Braziel and Mannur (2007, p. 7) stress that: 'diaspora forces us to rethink the rubrics of nation and nationalism, while reconfiguring the relations of citizens and nation-states'. Diaspora can, therefore, be seen as playing an important role in current re-thinkings of nationalism because it actively challenges notions of purity within nation-states, at least at a theoretical level. However, Soysal (2000, p. 2) notes that the dominant conceptualizations of diaspora presumptively accept the formation of tightly bounded communities and solidarities (on the basis of common cultural and ethnic references) between places of origin and arrival'. Wimmer and Glick Schiller (2002, p. 324) also stress the importance of considering the relationships between diaspora and nation-state building as well as the need for more critical analysis of diasporic groups.

Although studies of migrants and those in diaspora have focused on long-distance nationalism (Anderson 1998; Skrbis 1999; Glick Schiller and Fouron 2001), more research is needed to explore the ways in which diasporas and migrants construct collective identities and potentially self-essentializing or homogenizing nationalisms through the processes of re-territorialization; these need to be analyzed together with notions of hybridity and fluidity. As Brubaker (2005, p. 10) stresses, 'discussions of diaspora are often informed by a strikingly idealist, teleological understanding of the nation-state, which is seen as the unfolding of an idea of nationalizing and homogenizing of the 
population'. This needs to be addressed in work on both diaspora and migration. We need to be aware of the ways in which migrants and those in diaspora use such nationalist rhetoric to serve political purposes and analyze the ways in which migrants negotiate loyalties to multiple nationalisms in flexible and strategic ways (Ong 1999). This does not mean, however, that all conceptions of nationalism are extreme or exclusive and certainly nationalism is a complex notion that is situated, relational (Armstrong 1998, p. 2-3) and dynamic over time and space. This is an important point to make because it highlights the active nature of nationalism as a social construction; as a result it can be conceptualized as strategic, manipulative and ideological, as well as unifying and empowering.

It must also be remembered that individuals can belong to more than one group and can have multiple and fluid identities. However, certain identities may become more important at certain moments in time. For example, if a person feels threatened, or feels that their history is being erased, they may look to the past to try and re-create an 'authentic' ethnic identity to hold onto and which they might feel helps define who they are. It is perhaps unsurprising that the notion of ethnicity can become very meaningful to those in diaspora because it can become perceived as a way to belong and feel distinctive; however, as Radhakrishnan (2007, p. 120) asks: 'how is ethnic identity related to national identity? Is this relationship hierarchically structured such that "national" is supposed to subsume and transcend ethic identity, or does this relationship produce a hyphenated identity?' This is a difficult 
question to answer but it is one that often comes to the fore if people move, or are categorized according to ethnicity. Ethnicity then becomes a marker of identity, which can have positive and negative repercussions. As Radhakrishnan (2007: 127) goes on to note: 'the rhetoric of authenticity tends to degenerate into essentialism'. This highlights the dangers associated with searches for pure mythical pasts, roots and homelands, which many in diaspora seek to do. Anthias (1998) has also made the point that notions of diaspora do not automatically transgress notions of ethnicity because they rely on notions of ethnicity and origin in the homeland.

Migration often creates tangible changes to places and societies. This can be perceived positively; unfortunately others resort to purist thoughts of unity, homogeneity and exclusion in order to construct nations, spaces and places in static, idealized and romanticized ways. Immigration both accentuates difference and galvanizes a variety of ways to deal with difference and change. Within dynamic conceptions of national identity and nationalism as socially constructed, perceptions of migrants and those in diaspora can potentially become more open-ended and inclusive.

The future of nationalism in diverse societies: 'rescuing nationalism'?

This paper has raised many issues in relation to nationalism, migration and diaspora. It has highlighted the potentially problematic nature of nationalism and has stressed the need to consider the relationships 
between nationalism and purity as well as the double-edged nature of nationalism. As Bulmer and Solomos (2009, p. 590) also stress: "it is important that research and scholarship on these issues address the question of what explains the continuing role of nationalism as a source of mobilization and political identity formation".

There is a need, therefore, to research how and why nationalism changes over time and space within places that continue to count (Kivisto 2001) and how real people are involved in the process. At the same time, we need to consider the power relations that occur as constructions of long-distance nationalism continue to be created, manipulated and promoted by those in positions of power using networks such as the internet (Parham 2004; Bernal 2006; Eriksen 2007) as evidence suggests diasporic and transnational nationalisms continue to exist in virtual communities.

Nationalism is continuously re-created and performed through banal everyday acts and imagined communities in which the nation is made meaningful and diverse. Therefore, nationalism can be theorized as both 'top-down' and 'bottom-up'. It is this latter idea and the ways in interacts with the former that requires more research. Questions remain as to how in a globalizing world, nationalism continues to be important to everyday lives and identities and how, in the process, people can become included and excluded. To go beyond the 'dualisms' of nationalism requires research that unravels the often messy and ambivalent nature of nationalism, especially in relation to migration. Questions still remain around the lived realities and power relations of 
everyday nationalism and how and in what material ways, nationalism is constructed, enacted, performed, and experienced and who it is that is involved in its dispersal and promotion in historical and contemporary times (Jones and Fowler 2007; McCrone and Bechhofer 2008). What is also needed, therefore, is more research into meanings, spaces and repercussions of nationalism, at different scales, from the local to the supra-national (Thompson 2001; Boyle 2001) to explain and explore what Pryke (2003) has called 'micro-nationalism' and the ways in which top-down and bottom-up nationalisms interact and cross-cut.

It may therefore be important to re-imagine the notion of nationalism in more inclusive and flexible ways that allow diverse populations to feel as though they belong. However, the challenge for governments is how to encourage such nations without resorting to simplistic notions of the nation and us/them relationships. At the same time, how do governments respond to the needs of particular groups without the ability to label and categorize them somehow? The appeal of ethnicity is its classification of people and group relationships (Eriksen 2002) and as Levy (2000) stresses, cultural or ethnic identities, despite their dynamic and constructed nature, are a very real part of contemporary life. In the myriad complexity of a country, with many different dynamic identities, grounded in a variety of places, how do we create hospitable spaces that are inclusive, welcoming and that do not resort to easy and simplistic stereotyping of difference?

Tensions and differences within nations need to be negotiated and managed in such ways that do not accentuate us/them relationships 
and do not promote narrow-minded understandings of identity and difference. As a result, migrants, those in diaspora and those who feel marginalized, excluded, vulnerable and ignored in society can have their needs met without resorting to violence, conflict and potentially extreme identities and loyalties to places and movements beyond or in opposition to the state. Countries deal with their populations in different ways but the promotion of more purist notions of national and ethnic identity and the construction of immigrants 'flooding' in by the government and certain sections of the popular media is problematic (Gale, 2004; Greenslade 2005; de Haas 2008).

Migrants and those in diaspora are not a challenge to states, but an integral and important aspect of many of them. Reactionary and extreme measures to 'protect national security' have become more commonplace as strategic, manipulative, romanticized and historical myths of the 'national' are encouraged. This can create fear of the Other, racism and prejudice despite the many steps that have been made to combat irrational fear of difference. Vertovec (2007b, p. 966) has pointed out that:

...neighbourhoods need to be accepted as the spatially open, culturally heterogeneous, and socially variegated spaces that they are, not imagined as future cohesive or integrated communities. 
This is an important point to make as it stresses the need for more research on grounded everyday interactions into (mis)communication, alienation and the lack of cross-cultural respect and understanding that continues to exist despite numerous Western government attempts to educate its citizens in diversity. It seems that nationalism is still being perhaps inadvertently constructed in purist ways as the state tries to carve out its ideal national citizen. One could argue therefore that nationalism needs to be 'rescued' from its homogenizing and purist tendencies by an insistence on its plurality and multiplicity. Therefore, rather than dismissing nationalism, there is the potential to make it as meaningful, inclusive, broad and open-ended as possible.

Finding out how national identities are negotiated within and across boundaries can shed light on how nationalism is changing and what it means to people in the $21^{\text {st }}$ Century as there are increasingly more complex ways to belong. Detailed research on the daily materialities of nationalism as well as state discourses on nationalism at different scales and in different spaces and places will hopefully allow a more nuanced understanding of the continued importance, dynamicism and flexibility of nationalism. However, even if nationalism can be 'rescued', its purist tendencies will always be lurking in the background. 


\section{References}

Abell, J., Condor, S., Lowe, Robert D., Gibson, S. and Clifford, S. (2007) Who ate all the pride? Patriotic sentiment and English national football support, Nations and Nationalism, 13 (1), pp. 97-116.

Abbas, T. (2007) Muslim minorities in Britain: Integration, multiculturalism and radicalism in the post-7/7 period, Journal of Intercultural Studies, 28(3), pp. $287-300$

Allan, S. and Thompson, A. (1999) The time-space of national memory, in: K. J. Brehony and N. Rassool (Eds) Nationalisms Old and New, pp. 35-50. Basingstoke: Macmillan.

Amin, A. (2002) Ethnicity and the multicultural city: living with diversity, Environment and Planning A, 34, pp. 959-980.

Anderson, B. (1983) Imagined Communities. London: Verso

Anderson, B. (1999) The Spectre of Comparisons: Nationalism, Southeast Asia, and the World. London: Verso

Anthias, F. (1998) Evaluating 'diaspora': beyond ethnicity?, Sociology, 32(3), pp. 557-580. 
Armstrong, W. (1998) Belonging, ethnic diversity and everyday experience: co-existing Identities on the Italo-Slovene frontier, Transnational Communities Research Working Paper WPTC-98-05.

Balibar, E. (2005) Racism and nationalism, in: P. Spencer and H. Wollman (Eds) Nations and Nationalism: A Reader, pp. 163-172. Edinburgh: Edinburgh University Press.

Beissinger, M. (2005) How nationalisms spread - Eastern Europe adrift in the tides and cycles of nationalist contention, in: $\mathrm{P}$. Spencer and $\mathrm{H}$. Wollman (Eds) Nations and Nationalism: A Reader, pp. 258-274. Edinburgh: Edinburgh University Press.

Bernal, V. (2006) Diaspora, cyberspace and political imagination: the Eritrean diaspora online, Global Networks, 6(2) pp. 161-179.

Bhabha, H. (1994) The Location of Culture. London: Routledge

Billig, M. (1995) Banal Nationalism. London: Sage

Boyle, M. (2001) Towards a (re)theorization of the historical geography of nationalism in diasporas: the Irish diaspora as exemplar, International Journal of Population Geography, 7(6) pp. 429-446. 
Braziel, J. E. and Mannur A. (Eds) (2007) Theorizing Diaspora: A Reader. Malden MA: Blackwell.

Brubaker, R. (2005) The "diaspora" diaspora, Ethnic and Racial Studies 28(1), pp. 1-19.

Bulmer, M and Solomos, J. (2009) Introduction: Nationalism and national identities, Ethnic and Racial Studies, 32(4) pp. 587 - 590.

Calavita, K. (2005) Immigrants at the Margins: Law, Race, and Exclusion in Southern Europe. Cambridge: Cambridge University Press.

Cantle, T. (2001) Community Cohesion: A Report of the Independent Review. London: Home Office.

Carter, S. (2005) The geopolitics of diaspora, Area, 37(1), pp. 54-63.

Castles, S. (2004) Why migration policies fail, Ethnic and Racial Studies, 27, (2) pp. 205-227.

Castles, S. and Miller, M. (2003) The Age of Migration. London: Palgrave Macmillan 
Chatterjee, P. (2005) Whose imagined community? In: P. Spencer and

H. Wollman (Eds), Nations and Nationalism: A Reader, pp. 237-248. Edinburgh: Edinburgh University Press.

Cheong, P. H., Edwards, R., Goulbourne, H. and Solomos, J. (2007) Immigration, social cohesion and social capital: A critical review Critical Social Policy, 27(1) pp. 24-49.

Citrin, J., Lerman, A., Murakami, M. and Pearson, K. (2007) Testing Huntington: Is Hispanic Immigration a Threat to American Identity? Perspectives on Politics, (5)1, pp. 31-48.

Cohen, R. (1999) The making of ethnicity: A modest defence of primordialism in: E. Mortimer with R. Fine (Eds), People, Nation and State, pp. 3-11. London: IB Taurus.

Cohen, R. (1997) Global Diasporas. London: UCL Press.

Condor, S. (2006) Representing, resisting and reproducing ethnic nationalism: Official UK Labour Party representations of 'multicultural Britain', available online at: http://eprints.lancs.ac.uk/11178/

Cornelius, W. A. (2005) Controlling 'unwanted' immigration: Lessons from the United States, 1993-2004, Journal of Ethnic and Migration Studies, 31(4) pp. 775-794. 
Clifford, J. (1997) Routes: Travel and Translation in the Late Twentieth Century. Cambridge: Harvard University Press

Crowley, H and Hickman, M.J (2008) 'Migration, postindustrialism and the globalized nation state: social capital and social cohesion reexamined', Ethnic and Racial Studies, 31(7) pp. 1222 - 124.

Davis, U. (1997) Citizenship and the State: A Comparative Study of Citizenship Legislation in Israel, Jordan, Palestine, Syria and Lebanon. Reading: Ithaca Press.

De Haas, H. (2008) The myth of invasion: The inconvenient realities of African migration to Europe, Third World Quarterly, 29, (7) pp. 13051322

Delanty, (2003) Community. London: Routledge.

Delanty, G. (2008) Fear of Others: Social exclusion and the European crisis of solidarity, Social Policy and Administration, 42 (6) pp. 676690.

Duprez, D. (2009) Urban rioting as an indicator of crisis in the integration model for ethnic minority youth in France, Journal of Ethnic and Migration Studies, 35(5) pp. $753-770$ 
Dwyer, C. (1999) Contradictions of community: Questions of identity for young British Muslim women, Environment and Planning A (31) 53-68.

Ellis, M. and Almgren, G. (2009) Local contexts of immigrant and second-generation integration in the United States, Journal of Ethnic and Migration Studies, 35(7) pp. $1059-1076$

Eriksen, T.H. (2002) Ethnicity and Nationalism. London: Pluto Press.

Eriksen, T.H. (2007) Nationalism and the internet, Nations and Nationalism, 13(1) pp. 1-17.

Fenton, S. (2007) Indifference towards national identity: what young adults think about being English and British, Nations and Nationalism, 13(2) pp. 321-339

Fine, R. (1999) Benign Nationalism? The limits of the civic ideal' in: Edward Mortimer with Robert Fine (Eds), People, Nation and State. London: IB Taurus, pp. 149-161

Flynn, D. (2005) New borders, new management: the dilemmas of modern immigration policies, Ethnic and Racial Studies, 28(3) pp. 463490. 
Fortier, A. (2007) Too close for comfort: loving thy neighbour and the management of multicultural intimacies, Environment and Planning D: Society and Space, 25, pp. 104-119

Gale, P. (2004) The refugee crisis and fear: Populist politics and media discourse, Journal of Sociology, 40(4) pp. 321-340.

Gellner, E. (1983) Nations and Nationalism. Oxford: Blackwell.

Gilroy, P. (1999) It ain't where you're from, it's where you're at: The dialectics of diasporic identification in: S. Vertovec and R. Cohen (Eds), Migration, Diasporas and Transnationalism. Cheltenham: Elgar, pp. 280292.

Gilroy, P. (2000) Between Camps: Nations, Cultures and the Allure of Race. London: Allen lane, Penguin.

Glick-Schiller, N., Basch, L and Blanc-Szanton, C. (1999) Transnationalism: A new framework for understanding migration', in: S. Vertovec and R. Cohen (Eds), Migration, Diasporas and Transnationalism. Cheltenham: Elgar, pp. 299-314.

Glick Schiller and Fouron, G. (2001) Georges Woke Up Laughing: Long Distance Nationalism and the Search for Home. Durham and London: Duke University Press. 
Greenslade, R. (2005) Seeking Scapegoats: The Coverage of Asylum in the UK Press. London: Institute for Public Policy Research.

Grillo, R. (2007) An excess of alterity? Debating difference in a multicultural society, Ethnic and Racial Studies, 30(6) pp. 979 - 998.

Grillo, R. (2005) "Saltdean Can't Cope": Response to asylum-seekers in an English seaside suburb, Ethnic and Racial Studies 28, pp. 235-260.

Grillo, R. (2003) Cultural essentialism and cultural anxiety, Anthropological Theory, 3(2) pp. 157-173.

Guarnizo, L. and Smith, M.P. (1998) The locations of transnationalism', in: M.P. Smith and L. Guarnizo, (Eds), Transnationalism from Below. New Brunswick, NJ: Transaction Publishers.

Haddad, Y and Balz, M (2006) The October riots in France: A failed immigration policy or the Empire Strikes Back? International Migration, 44(2) pp.23-34.

Hage, G. (2000) White Nation: Fantasies of White Supremacy in a Multicultural Society. London: Routledge. 
Hall, S. (1999) Cultural identity and diaspora, in: S. Vertovec and R. Cohen (Eds), Migration, Diasporas and Transnationalism. Cheltenham: Elgar, pp. 299-314.

Hobsbawm, E and Ranger, T. (Eds 1983) The Invention of Tradition. Cambridge: Cambridge University Press.

Hollifield, J (2004) The emerging migration state, International Migration Review, 38(3) 885-912.

Hubbard, P. (2005) 'Accommdating Otherness: anti-asylum centre protest and the maintenance of white privilege, Transactions of the Institute of British Geographers, 30(1) pp. 52-65.

Hudson, M., Phillips, J. Ray, K. And Barnes, H. (2007) Social Cohesion in Diverse Communities, Joseph Rowntree Foundation.

Hussain, Y. And Bagguley, P. (2005) Citizenship, ethnicity and identity: British Pakistanis after the 2001 'riots', Sociology, 39(3) pp. $407-425$ 
Hutnyk, J. (2005) Hybridity, Ethnic and Racial Studies, 28(1) pp. 79102.

Johnston, R, Forrest, J and Poulsen, M (2002) Are there ethnic enclaves/ghettos in English cities?, Urban Studies, 39(4) pp. 591-618.

Jones, R. and Fowler, C. (2007) National élites, national masses: oral history and the (re)production of the Welsh nation, Social \& Cultural Geography, 8(3) pp. $417-432$.

Joppke, C. (2004) The retreat of multiculturalism in the liberal state: theory and policy The British Journal of Sociology, 55(2) pp. 237-257.

Kalra, V.S. and Kapoor, N. (2009) Interrogating segregation, integration and the community cohesion agenda, Journal of Ethnic and Migration Studies, 35 (9) pp. 1397- 1415.

Kastoryano, R. (2007) Transnational nationalism: redefining nation and territory, in: S. Benhabib, I. Shapiro, D. Petranovic (Eds), Identities, Affiliations and Allegiances. Cambridge: Cambridge University Press, pp. 159-180.

Kivisto, P. (2001) Theorizing transnational immigration: A critical review of current efforts, Ethnic and Racial Studies 24(4) pp. 549-577. 
Kong, L. and Yeoh, B. (1997) The construction of national identity through the production of ritual and spectacle: An analysis of National Day parades in Singapore Political Geography, 16(3) pp. 213-239.

Levy, J. (2000) The Multiculturalism of Fear, Oxford: Oxford University Press.

Marden, P. (1997) Geographies of dissent: Globalization, identity and the nation, Political Geography, 16(1) pp. 37-64.

Marfleet, P. (2006) Refugees in a Global Era. Basingstoke: Palgrave Macmillan.

Massey, D. (Ed 2008) New faces in New Places: The Changing Geography of American Immigration, Russell Sage Foundation.

Massey, D. (2007) World City, London: Polity Press.

McCrone, D. and Bechhofer, F. (2008) National identity and social inclusion, Ethnic and Racial Studies, 31(7) pp. 1245 - 1266

Meyers, D.W. (2003) Does "smarter" lead to safer? An assessment of the US border accords with Canada and Mexico, International Migration, 41(4) pp. 5-44. 
Mitchell, K. (2004) Geographies of identity: Multiculturalism unplugged, Progress in Human Geography, 28(5) pp. 641-651.

Mitchell, K. (1997) Different diasporas and the hype of hybridity, Environment and Planning D: Society and Space, 14, pp. 487-499.

Nagel, C. and Staeheli, L. (2005) 'We're just like the Irish': narratives of assimilation, belonging, and citizenship among Arab American activists' Citizenship Studies, 9(5) pp. 485-498.

Nagel, C. (2002) Constructing difference and sameness: the politics of assimilation in London's Arab Communities, Ethnic and Racial Studies, 25(2) pp. 258-287.

Noble, G. and Poynting, S. (2008) The affective regulation of migrant belonging in Australia in: Rachel Pain and Susan Smith (Eds) Fear: Critical Geopolitics and Everyday Life. London: Ashgate, pp. 129-139.

Nuttall, S. and Coetzee, C. (1998) Negotiating the Past: The Making of Memory in South Africa. Cape Town: Oxford University Press. 
Nyamnjoh, F.B. (2006) Insiders and Outsiders: Citizenship and Xenophobia in Contemporary Southern Africa, London: Zed Books

Ong, A. (1999) Flexible Citizenship: The Cultural Logics of Transnationality. London and Durham: Duke University Press.

Pantoja, A (2005) Transnational ties and immigrant political incorporation: the case of Dominicans in Washington Heights, New York, International Migration, 43(4) pp. 123-146.

Parekh, B. (2000) The Future of Multi-Ethnic Britain. London: Profile Books.

Parham, A. A. (2004) Diaspora, community and communication: internet use in transnational Haiti Global Networks, 4(2) pp. 199 - 217

Papastergiadis, N. (2001) The Turbulence of Migration. London: Polity Press.

Peach, C. (2009) Slippery segregation: Discovering or manufacturing ghettos? Journal of Ethnic and Migration Studies, 35(9) pp. 13811395

Phillips, D. (2006) Parallel lives? Challenging discourses of British Muslim self-segregation, Environment and Planning A, 24(1) pp. 2540. 
Portes, A., Escobar, C. and Arana, R. (2008) Bridging the gap: transnational and ethnic organizations in the political incorporation of immigrants in the United States, Ethnic and Racial Studies, 31(6) pp. $1056-1090$.

Portes, A., Fernández-Kelly, P. and Haller, W. (2005) Segmented assimilation on the ground: The new second generation in early adulthood, Ethnic and Racial Studies, 28 (6) pp. 1000 - 1040

Poynting, S. and Mason, V. (2007) The resistible rise of Islamophobia: Anti-Muslim racism in the UK and Australia before 11 September 2001, Journal of Sociology, 43(1) pp. 61- 86.

Pryke, S. (2003) British Serbs and long distance nationalism, Ethnic and Racial Studies, 26(1) pp. 152-172.

Radhakrishnan, R. (2007) Ethnicity in an age of diaspora, in: J. Evans Braziel and A. Mannur (Eds), Theorizing Diaspora: A Reader. Malden MA: Blackwell, pp. 119-132.

Rapport, N. And Dawson, A. (1998) Migrants of Identity: Perceptions of 'Home' in a World of Movement. Oxford: Berg. 
Rose, G. (1995) The Interstitial perspective: A Review Essay on Homi Bhabha's The Location of Culture, Environment and Planning D: Society and Space, 13, pp. 365-373.

Safran, W. (1991) Diasporas in modern societies: myths of homeland and return, Diaspora, 1, pp. 83-99

Said, E. (1986) After the Last Sky: Palestinian Lives. London: Vintage.

Said, E. 1990 'Reflections on exile', in: R. Ferguson, M. Gever, T. Minhha and C. West (Eds) Out There, Marginalization and Contemporary Cultures, Cambridge: MIT Press, pp. 357-366.

Said, E. (2000) Invention, memory and place, Critical Inquiry, 26, pp. 175-192

Said, E. (2001) The End of the Peace Process: Oslo and After. London: Granta Books.

Sales, R. (2005) Secure borders, safe Haven: A contradiction of terms?, Ethnic and Racial Studies, 28(3) pp. 445-62.

Shapiro, M.J. (2000) National times and other times: re-thinking citizenship, Cultural Studies, 14(1) pp. 79-98. 
Schuster, L. (2003) 'Asylum seekers: Sangatte and the tunnel', Parliamentary Affairs, 56(3) pp 506-522.

Schuster, L and Solomos, J. (2004) Race, immigration and asylum: New Labour's agenda and its consequences, Ethnicities, 4(2) pp. 267-300.

Sheffer, G. (1999) The emergence of new ethno-national diasporas, in: S. Vertovec and R. Cohen (Eds), Migration, Diasporas and Transnationalism. Elgar: Cheltenham, pp. 396-419.

Silberman, R., Alba, R. and Fournier, I. (2007) Segmented assimilation in France? Discrimination in the labour market against the second generation, Ethnic and Racial Studies, 30 (1), pp. 1 - 27

Skrbis, Z. (1999) Long-Distance Nationalism: Diasporas, Homelands and Identities. Aldershot: Ashgate Publishing.

Soysal, Y. (2000) Citizenship and identity: Living in diasporas in post-war Europe, Ethnic and Racial Studies, 23(1) pp. 1-15.

Soysal, Y. (1998) Towards a postnational model of membership: in Gabriel Shafir (Ed), The Citizenship Debates: A Reader. University of Minnesota Press: Minneapolis, pp. 189-221. 
Soysal, Y. (1994) The Limits of Citizenship: Migrants and Postnational Membership in Europe. Chicago: Chicago University Press.

Smith, A.D. (1999) The nation: real or imagined, in: E. Mortimer with R. Fine (eds), People, Nation and State. London: IB Taurus, pp. 36-42.

Spencer, P and Wollman, H. (2005) Good and bad nationalisms, in: P. Spencer and H. Wollman (Eds), Nations and Nationalism: A Reader, Edinburgh: Edinburgh University Press, pp. 197-217.

Spencer, S. (Ed 2003) The Politics of Migration: Managing Opportunity, Conflict and Change. Oxford: Blackwell.

Tambini, D. (2001) Post-national citizenship, Ethnic and Racial Studies, 24(2) pp. 195-217.

Taylor, P.J. (1997) Political Geography: World Economy, Nationstate and Locality. Harlow: Longman

Thompson, A. (2001) Nations, national identities and human agency: putting people back into nations, The Sociological Review, 49(1) pp. $18-32$. 
Tölölyan, K. (1991) The nation-state and its others: In lieu of a preface, Diaspora , 1(1) pp. 3-7.

Triandafyllidou, A. (2000) The political discourse on immigration in Southern Europe: A critical analysis, Journal of Community and Applied Social Psychology 10, pp. 373-389

Triandafyllidou, A (1998) National identity and the 'Other" Ethnic and Racial Studies 21(4) pp. 593-612.

Valins, O (2003) Stubborn identities and the construction of socio-spatial boundaries: ultra Orthodox Jews living In contemporary Britain Trans Inst Br Geogr. 28 (2) pp. 158-175.

Van Houtum, and Pijpers, R. (2007) The European Union as a gated community: the two faced border and immigration regime of the EU, Antipode, 39(2) pp. $291-309$.

Varsanyi, M. (2005) The rise and fall (and rise again?) of non-citizen voting: Immigration and the shifting scales of citizenship and suffrage in the US, Space and Polity, 9(2) pp. 113-134. 
Vasta, E. (2007) From ethnic minorities to ethnic majority policy: Multiculturalism and the shift to assimilationism in the Netherlands, Ethnic and Racial Studies, 30(5) pp. $713-740$.

Vertovec, S. (2007a) Super-diversity and its implications, Ethnic and Racial Studies, 30(6) pp. 1024-1054.

Vertovec, S. (2007b) Introduction: New directions in the anthropology of migration and multiculturalism, Ethnic and Racial Studies, 30(6) pp. 961-978.

Vertovec, S (2004) Migrant transnationalism and modes of transformation, International Migration Review, 38(3) pp. 970-1001.

Waldinger, R. (2007) The bounded community: Turning foreigners into Americans in twenty-first century L.A., Ethnic and Racial Studies, 30(3) pp. $341-374$.

Wimmer, A. and Glick-Schiller, N. (2002) Methodological nationalism and beyond: nation-state building, migration and the social sciences, Global Networks, 2(4) pp. 301-334. 
Winders, J. (2007) Bringing back the (b)order: Post-9/11 Politics of immigration, borders, and belonging in the contemporary US South, Antipode, 39(5) pp. 920-942.

Wise, A. (2010) Sensuous Multiculturalism: Emotional Landscapes of Inter-Ethnic Living in Australian Suburbia', Journal of Ethnic and Migration Studies, 36 (6), pp. $917-937$

Yeoh, B. and Huang, S. (2000) Home and away: Foreign domestic workers and negotiations of diasporic identity in Singapore, Women's Studies International Forum, 23(4) pp. 413-429.

Zolberg, A. B. (2006) A Nation by Design: Immigration Policy in the Fashioning of America, Harvard University Press. 